\title{
Psykodynamisk og kognitiv terapi bør likestilles
}

\author{
Kognitiv terapi er veldokumentert og vektlegges i helsemyndighetenes retningslinjer for behandling av \\ psykiske lidelser. Allikevel kan en psykiater i dag gå hele sin utdanning uten å motta psykoterapiveiledning \\ i kognitiv terapi.
}

Psykoterapiveiledning har lang tradisjon innen psykiaterutdanningen. Kravet til veiledning er nå 105 timer, der to av årene (70 timer) skal være psykodynamisk veiledning og et av årene kan være psykodynamisk, kognitivt eller gruppeterapeutisk fundert. Man kan altså fullføre en utdanning i psykiatri uten å ha mottatt psykoterapiveiledning i kognitiv tilnærming. En kandidat som virkelig er interessert i kognitiv terapi, får maksimalt godkjent ett av tre år med veiledning innenfor denne tradisjonen. Det er nødvendig at fremtidige psykiatere får anledning til å skaffe seg mer omfattende kjennskap til denne psykoterapiformen enn det som er tilfellet i dagens spesialistutdanning.

\section{Behov for endring}

Norsk Forening for Kognitiv Terapi har i flere år prøvd å få klarhet $i$ årsakene til at psykodynamisk terapi og kognitiv terapi ikke er likestilt i utdanningen. Psykoterapiutvalget synes å være av den oppfatning at lege-pasient-relasjonen best ivaretas i den psykodynamiske tradisjonen. Dessuten har utvalget argumentert med at det er mangel på veiledere i kognitiv terapi.

Det er vanskelig å forstå den faglige begrunnelsen for psykoterapiutvalgets standpunkt. Kognitiv terapi har fått stor utbredelse og anbefales av helsemyndighetene fordi den har godt dokumenterte resultater ved et bredt spekter av psykiske lidelser. Lege-pasient-forholdet og betydningen av en god terapeutisk allianse står sentralt i kognitiv terapi. Det legges vekt på terapeutisk empati, positiv anerkjennelse og ekthet, hvordan tilpasse relasjonen til pasientens forutsetninger, håndtering av samarbeidsproblemer og reparasjon av alliansebrudd. En betydelig andel av forskning og metodeutvikling for den terapeutiske allianse skjer i dag innenfor kognitiv terapi (1).

Kognitiv terapi, også kalt kognitiv atferdsterapi, utviklet seg fra 1960-årene og er fundert på empiriske metoder og oppdatert teoriforståelse fra klinisk psykiatri og psykologi. Behandlingen har dokumentert nytteverdi ved depresjon (2), angstlidelser (3), psykose (4) og spiseforstyrrelser (5). Kognitiv terapi er anbefalt ved kroniske smerter (6), kronisk utmattelse (7) og søvnproblemer (8), og inngår som et viktig supplement $\mathrm{i}$ behandling av en rekke somatiske sykdommer $(9,10)$. Relasjonelle aspekter som allianse og overføringsfenomener er grundig belyst (11). Modellene etterprøves og utvikles kontinuerlig gjennom vitenskapelige studier. Det er bakgrunnen for at kognitiv terapi fremheves i nasjonale retningslinjer for behandling, også av norske helsemyndigheter $(12,13)$.

\section{Veilederne finnes}

Det er i dag 35 psykiatere som er veiledere i kognitiv terapi og om lag 180 som er psykodynamiske veiledere. Andelen godkjente veiledere som faktisk driver veiledning er ukjent. Grunnlaget for å underordne en terapiretning på bakgrunn av antallet leger med spesialiteten, er aldri blitt forklart. Selv er jeg veileder i kognitiv terapi og seksjonsoverlege ved en voksenpsykiatrisk poliklinikk. Det siste året har jeg startet innføringsseminar i psykodynamisk terapi, ut fra genuin interesse og respekt for denne terapeutiske tilnærmingen. Jeg har etter hvert fått flere års erfaring fra psykisk helsevern og hvilke utfordringer som møter legene der.

\section{«Tiden er moden for at Legeforeningen like- stiller kognitiv terapi og psykodynamisk terapi»}

Jeg mener at den største trusselen mot vårt virke som psykiatere ansatt $i$ det offentlige helsevesen fremover er generell tidsnød, som kan vanskeliggjøre psykoterapeutisk utøvelse. Det er et uheldig aspekt ved den overnevnte diskusjonen mellom to av de ledende terapeutiske tilnærmingene at den kamuflerer dette mer betydelige problem. Vi risikerer at andre yrkesgrupper overtar denne viktige og interessante delen av våre arbeidsoppgaver. Dette tror jeg er uheldig for både pasientene og oss! Vi som ivrer for psykoterapi som del av psykiaterens virke, bør kunne stå samlet for å motvirke denne utviklingen.

\section{Kompetansekrav til psykiateren}

1.10. 2011 tok staten ved Helsedirektoratet over spesialistgodkjenningen. Det er uklart hva dette vil bety i praksis. Legeforeningen vil trolig fortsatt ha en viktig rolle i forberedelse og innstilling av saker. Det er likevel grunn til å tro at direktoratet vil være interessert i å skape en sammenheng mellom terapianbefalinger gitt i ulike retningslinjer for behandling og i prioriteringsveiledere og den kompetansen som psykiatere blir sittende igjen med etter endt utdanning. Det er også grunn til å tenke at pasientrettighetslovens prinsipp om rett til medvirkning og informasjon vil kreve god faglig bredde i det offentlige helsevesen og i psykiaterens faglige kompetanse. For ledere i det offentlige helsevesen vil bredden i kompetanse hos medarbeiderne være avgjørende for at man skal kunne drive en robust virksomhet med tilbud til pasienter med de fleste psykiatriske tilstander og med ulike preferanser.

\section{Behov for åpen debatt}

Tiden er moden for at Legeforeningen likestiller kognitiv terapi og psykodynamisk terapi. Kognitiv terapi er dokumentert effektiv og gir høy grad av pasienttilfredshet, og mange leger finner det inspirerende å lære seg og å utøve denne terapiformen. Argumentene mot slik likestilling virker å være preget av fordommer mot kognitiv terapi hos noen av de psykiaterne som sitter med psykodynamisk kompetanse og mangler kunnskap om kognitiv terapi.

Vi bør ha en åpen debatt om hvilken form endringene kan ha. Én mulighet er at alle psykiatere blir gjort kjent med de to individuelle psykoterapiretningene. Dette kunne skje med henholdsvis ett år psykodynamisk og ett år kognitiv veiledning i tillegg til ett år med valgfri fordypning (psykodynamisk, kognitiv eller gruppeanalytisk). Da ville man også få fremhevet at det er sentrale likhetstrekk mellom tilnærmingene og forebygge en polarisering som bare tjener til å svekke psykoterapiens omdømme. Her har vi psykiatere viktige felles holdninger. Samarbeidet mellom de to miljøene kunne også vært bedret gjennom å lage et felles psykoterapirettet program i teoridelen under det obligatoriske grunnkurset for leger i spesialisering.

Det offentlige helsevesen ser ut til å bli stadig mer preget av begreper og løsninger hentet fra næringslivet. Tiden som tillates brukt av leger på psykoterapi kan lide under denne utviklingen. Derfor må pasientens mulighet for individuell psykoterapi gis prioritet og settes på dagsordenen av to kompetente fagmiljøer preget av gjensidig respekt. 


\section{Kjetil Horn}

kjehorn@online.no

DPS Moss

Sykehuset Østfold

Kjetil Horn (f. 1966) er seksjonsleder ved Moss distriktspsykiatriske senter og nestleder i Norsk Forening for Kognitiv Terapi. Ingen oppgitte interessekonflikter.

\section{Litteratur}

1. Gilbert P, Leahy RL. The therapeutic relationship in the cognitive behavioural psychotherapies. New York: Routledge, 2007

2. Beck AT, Rush AJ, Shaw BF et al. Cognitive therapy of depression. New York: Guilford Press, 1979.
3. Barlow DS. Anxiety and its disorders. The nature and treatment of anxiety and panic. New York: Guilford Press, 2002.

4. Kingdon D, Turkington D. Cognitive therapy of schizofrenia. New York: Guilford Press, 2005.

5. Fairburn CG. Cognitive behavior therapy and eating disorders. Oxford: Oxford University Press, 2008.

6. Morley S, Eccleston C. Williams AC. Systematic review and meta-analysis of randomised, controlled trials of cognitive behaviour therapy and behaviour therapy for chronic pain in adults, excluding headache. Pain 1999; 80: 1-13.

7. Kinsella P. Cognitive behavioral therapy for chronic fatigue syndrom. A guide for clinicians. London. Routledge, 2007.

8. Perlis ML, Jungquist C, Smith MT et al. Cognitive behavioral treatment of insomnia. A session-bysession guide. New York: Springer, 2005

9. Gulliksson M, Burell G, Vessby B et al. Randomized controlled trial of cognitive therapy vs standard treatment to prevent recurrent cardiovascular events in patients with coronary heart disease. Arch Intern Med 2011: 17: 134-40.

10. Foley E, Baillie A, Huxter M et al. Mindfulnessbased cognitive therapy for individuals whose lives have been affected by cancer: A randomized controlled trial. J Consult Clin Psychol 2010; 78: 72-9.

11. Safran JD, Segal ZS. Interpersonal process in cognitive therapy. New York: Basic Books, 1990.

12. Nasjonale retningslinjer for diagnostisering og behandling av voksne med depresjon

i primærhelsetjenesten og spesialisthelsetjenesten. Oslo: Helsedirektoratet, 2009

13. Psykisk helsevern for voksne, prioriteringsveileder. Veiledertabell november 2008. Oslo: Helsedirektoratet, 2008

Mottatt 21.6. 2011, første revisjon innsendt 18.8. 2011, godkjent 15.9. 2011. Medisinsk redaktør Anne Kveim Lie.

\section{Overflødig undersøkelse?}

Som helsestasjonslege i over 30 år har jeg samvittighetsfullt utført Moros refleks ved seksukerskontrollen. Jeg brukte å utløse den ved å la barnets hode $\mathrm{i}$ hånden min plutselig falle noen centimeter. Barnet slår da ut med armene. I løpet av disse årene har jeg ikke oppdaget ett eneste avvik av betydning.

Dette har satt meg på tanken om at denne undersøkelsen kanskje er overflødig? Refleksen synes å være et uttrykk for at barnet blir skremt. Den har kanskje en beskyttende effekt, slik at nyfødte unger blir behandlet forsiktig.

Moderne forskning på tilknytning tyder på at det første halvåret av barnets liv har stor betydning for tilknytningen til andre mennesker. I hvilken alder spesielle opplevelser begynner å få betydning for den videre utvikling er omdiskutert. Enkelte mødre får inntrykk av at legen er ufølsom når han fremkaller en fryktreaksjeon hos barnet. Og hvis sjekking av Moros refleks strengt tatt ikke er medisinsk nødvendig, er det kanskje like godt å la det være?

\section{Arne Tveit}

arne.tveit@broadpark.no

Bergen

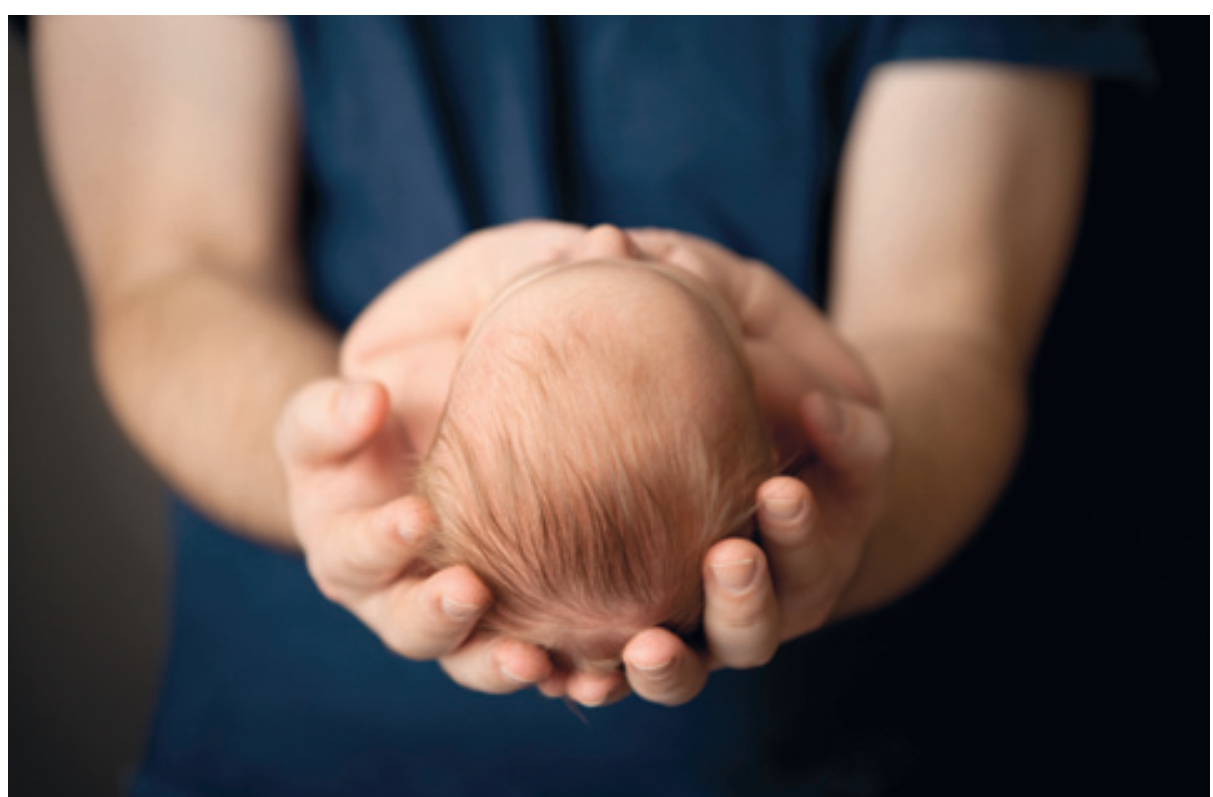

Illustrasjonsfoto Istockphoto

Arne Tveit (f. 1928) er pensjonert barnelege. Ingen oppgitte interessekonflikter.
Mottatt 2.8. 2011 og godkjent 1.9. 2011. Medisinsk redaktør Anne Kveim Lie. 